\title{
In Search of Englishness: A Study of the Historical Novel during the Victorian Era
}

\author{
Masoud Farahmandfar ${ }^{1} \&$ Sarah Catherine Household-Ilkhani ${ }^{2}$ \\ ${ }^{1} P h D$ candidate in English literature at Shahid Beheshti University (Iran). \\ Email: masoudfarahmandfar@gmail.com \\ ${ }^{2}$ Professor of English literature at Shahid Beheshti University (Iran).
}

Received January 21, 2017; Revised March 1, 2017; Accepted April 5, 2017; Published May 7, 2017.

\begin{abstract}
Historical novels are not only the legitimate progeny of a nation's becoming conscious of its own identity, they also contribute to fortify that nationalist discourse. In a sense, the very beginning of the historical novel is entwined with the emergence of a widespread consciousness about the idea of nation(-hood); nevertheless, studies of the historical novel (and its relation and contribution to national identity) have remained under-investigated. The abiding aim of the present study is thus to examine this relationship, to draw attention to historical and cultural dimensions of Englishness. The present paper examines the influence of national ideology on fictional historiography, and focuses on the ways some English novelists, during the Victorian era, have reflected upon their Englishness.
\end{abstract}

Keywords: Englishness; the nation; history; the historical novel; the Victorian era.

Representations of the past play a vital role in establishing images of identity-and indeed, identities of both place and people.

—Andrew Higson, Film England (2010: 191)

Since the rise of the English novel in the early $18^{\text {th }}$ century, an interest in history and the historical has been recognizable. It was partly due to the fact that before the emergence of the novel 'historiography' has been the most important prose genre. Yet, while a historian may make general statements about periods or characters to examine the nexus of past events and the processes of their development, the novelist will make particularized statements, re-imagining, in an inexhaustible manner, what it might be felt like living in the past, in another era. For example, the "I" that opens Daniel Defoe's classic Robinson Crusoe (1719) — set "in the year 1632, in the city of York" - particularizes the geographical and the historical reality of $17^{\text {th }}$-century England:

I was born in the Year 1632, in the City of York, of a good Family, tho' not of that Country, my Father being a Foreigner of Bremen, who settled first at Hull. He got a good Estate by Merchandise, and leaving off his Trade, lived afterward at York, from whence he had married my Mother, whose Relations were named Robinson, a very good Family in that Country, and from whom I was called Robinson Kreutznaer; but by the usual Corruption of Words in England, we are now called, nay we call our selves, and write our Name Crusoe, and so my Companions always call'd me.

(c) AesthetixMS 2016. This Open Access article is published under a Creative Commons Attribution Non-Commercial 4.0 International License (http://creativecommons.org/licenses/by-nc/4.o/), which permits non-commercial re-use, distribution, and reproduction in any medium, provided the original work is properly cited. For citation use the DOI. For commercial re-use, contact editor@rupkatha.com 
I had two elder Brothers, one of which was Lieutenant Collonel to an English Regiment of Foot in Flanders, formerly commanded by the famous Coll. Lockhart, and was killed at the Battle near Dunkirk against the Spaniards. (Defoe 5)

As these few sentences makes clear the novel is not untouched by history; the writer tells us about the war against the Spanish, evoking the memory of the Anglo-Spanish War (1585-1604), especially the 1588 Spanish Armada. Even the narrator's family name has a history. So, with a few sentences the writer easily yet masterfully conveys the "sentiment de l'existence" of early seventeenth century (Fleishman 4).

Writing about the past helped novelists reflect upon contemporary issues and articulate national sentiments. Such an appeal to national character allowed the historical novel flourish as a respectable, independent genre, as the "close connection of the vogue of Scott and the rise of nationalism suggests" (Fleishman ix). Therefore, the rise of nationalism in the late $18^{\text {th }}$ century and the early $19^{\text {th }}$ century was of great moment in the growth and development of the historical novel.

Accordingly, the present paper examines this fructuous relation of the historical novel to national identity in its origin in the nineteenth century. We will look at some representative novels in English literature which use the historical form to comment on the present ordeals and fortunes of their nation.

\section{Nineteenth-Century Historical Novels and the Discourse of the Nation}

Nation and national awareness are relatively new phenomena. Ernest Renan in his historic lecture at the Sorbonne in $\mathbf{1 8 8 2}$-which addressed the question "What is a nation?-clearly states that nations are "something fairly new in history. Antiquity was unfamiliar with them" (Renan 9). This idea is later repeated in the work of Ernest Gellner and Benedict Anderson. After the collapse of the traditional order of kings, nobilities and the clergies, the resulting gap was soon filled with yet another legalizing system. Nations appeared right at the time when traditions and religions lost their power. The collapse of the traditional feudal system, secularization of society-which was due to the advancement of natural sciences-and prevalence of rationalism and industrialism paved the way for the emergence of a strong sense of nationhood as a structural evolution, for the transition of traditional societies to modern ones.

Likewise, the cultivation of the historical imagination is a comparatively newcomer "because the mediaeval Christian mind had no conception of history as an endless chain of cause and effect or of radical separations between past and present" (Bloch, cited in Anderson 23). They were stuck in the imminency of time; they "thought they must be near the end of time, in the sense that Christ's second coming could occur at any moment" (Bloch, cited in Anderson 23). It was only after the Enlightenment that the concept of history and historiography becomes significant. Lukács also believes that "it was only during the last phase of the Enlightenment that the problem of the artistic reflection of past ages emerges as a central problem of literature" (Lukács 20). The notion of 'historicism,' as "the new historical approach," is introduced in this period-and idea which not only considers history "in an evolutionary pattern of growth," but also does see the past "as a peculiarly national affair" (Fleishman 18-19). Therefore, there is a symbiotic interrelationship between history and nation.

In Europe, national sentiments developed with the rise of the middle class, and the favorite genre of the middle class was the novel: "the novel in general came to be widely regarded 
as the principal source for a 'History of National Manners"' (Parrinder 25). According to Benedict Anderson, developments in the public readership of newspapers and novels were influential in shaping imagined communities, for the novel "provided the technical means for 're-presenting' the kind of imagined community that is the nation" (Parrinder 25). The global rise of the print industry increased literacy in vernacular languages and let the masses read and imagine themselves as members of a national community. In particular, historical novels managed to engage readers in considering the nation as a continuity over time-and nobody did it better than Sir Walter Scott (1771-1832).

\section{"How Easy Doth He Take All England Up!" Scott and the Idea of National Unity}

The name of the historical novel is often tied to the name of Sir Walter Scott as its architect. In fact, "[n]o one can write a sound history of historical writing in the nineteenth century without giving generous credit to Walter Scott" (Croce, cited in Humphrey 2). Scott translated history into national narratives and thereby generated a new era in fiction. This however does not mean that novels with historical subjects are not to be found before Scott's Waverley or 'Tis Sixty Years Since (1814), which is often considered the first proper historical novel. For example, Thomas Leland's historical romance Longsword (1762), Maria Edgeworth's regional novel Castle Rackrent (180o), and Jane Porter's four-volume novel Thaddeus of Warsaw (1803) are historical by subject; even the Gothic novel of the late 18th century is taken by some critics to be "a key type of historical fiction" (de Groot 16) - though definitely a nightmarish one. Nonetheless, these allegedly historical novels lack, in the words of Georg Lukács in The Historical Novel, "derivation of the individuality of characters from the historical peculiarity of their age" (19). In other words-and for our current consideration - they do not "reflect the essential characteristics of contemporary England" (ibid. 20). Scott's novels however capitalize on the historical form-not out of a romantic nostalgia-to comment on current issues.

As already mentioned, the beginning of the historical novel is linked to the emergence of nation-states and the awakening of national(-ist) sentiments, which are intrinsically aftermath of the late $18^{\text {th }}$ century social turmoils, particularly the 1789 French Revolution, that made history, for the first time, a mass experience. This increasing historical awareness reached its peak after the fall of Napoleon (1814). It is no accident that Scott's Waverley-usually considered the first historical novel-appeared right about the time, when Britain "was a victorious nation, apparently at the height of her power and prestige" (Lowe 1). Here Scott juxtaposes the "age-old steadfastness of English development amidst the most terrible crises" (Lukács 37) with the turbulence and disorder on the Continent. The story could be read as an invitation for reserving national unity and evading extremism.

The story of Waverley is set around the second Jacobite Rebellion of 1745: "The time which the author has chosen for the historical part of his tale is a period which no Briton can look back without the strongest emotions and the most anxious interest" (Hayden 68). The 1745 commotion was an immediate threat to Great Britain's solidarity and its invaluable Act of union.

The Glorious Revolution of 1688 peacefully deposed King James II of England (James VII of Scotland), who was a Roman Catholic, and instated the Protestant William of Orange. Thereafter, Catholic devotees of the dethroned James, the Jacobites, sought to reinstate the Stuarts. The agitations eventually ceased to exist when the Pretender (Bonnie Prince Charlie) is defeated at the Battle of Culloden. 
Edward Waverley, the eponymous hero of the novel, begins his (circle-round) journey in England, travels through the Lowlands and the Highlands in Scotland, with wavering sympathies, only to see the damage wrought upon the land by provincialism and extremism. Gaining maturity, he heads back to England to stay on the side of rationality. This circular quest reveals both Scott's philosophy of history and,' on another level, the character of England's national development.

For Scott societies develop in differing stages throughout history, and he acknowledges "historical differentiation in the midst of national continuity" (Fleishman 25). He supported, at least in public, a fruitful unity throughout the British Isles, and he was against the Jacobite cause because the nation "is the culmination of a long past of endeavors, sacrifice and devotion" (Renan 19). The British nation for Scott was the culmination of the Glorious Revolution and the Act of Union, so he does not allow separatist bands endanger it. That is why at the end of Waverley Edward "unplaids [himself] on the first opportunity" (Scott, 2013: 339), harshly blames Mac-Ivor for "wrapping the whole nation in fear and mourning" (409), and leaves the Highlands for "the smiling neatness of English cottages" (45). The marriage of Edward (of England) and Rose (of Scotland) at the end of the novel is a strong, supporting reference to the 1707 Union of England and Scotland.

In another of his bestselling novels Ivanhoe (1820) Scott creates a new historical tale of English origins. The story is set in late twelfth century England (ca. 1193-4) and narrates the antagonism between Saxons and Normans more than a century after the Battle of Hastings (1066):

Four generations had not sufficed to blend the hostile blood of the Normans and AngloSaxons, or to unite, by common language and mutual interests, two hostile races, one of which still felt the elation of triumph, while the other groaned under all the consequences of defeat. ... The condition of the English nation was at this time sufficiently miserable. King Richard was absent a prisoner, and in the power of the perfidious and cruel Duke of Austria. Even the very place of his captivity was uncertain, and his fate but very imperfectly known to the generality of his subjects, who were, in the meantime, a prey to every species of subaltern oppression.

Prince John, in league with Philip of France, Coeur-de-Lion's mortal enemy, was using every species of influence with the Duke of Austria, to prolong the captivity of his brother Richard, to whom he stood indebted for so many favors. (Scott, 1996: 86)

The novel is brimmed with ethno-racial tensions and conflicts: Cedric the Saxon, Ivanhoe's father ("the solitary oak"), is "under a vow never to step more than three steps from the dais of his own hall to meet any who shares not the blood of Saxon royalty" (ibid. 53) while Normans talk of "dog Saxons and accursed Jews" (327) and "preparing these Saxon hogs [Cedric and Athelstane] for the slaughter-house" (269). Every layer of the story is imbued by the notions of national identity and racial difference. Many a stereotypical reference can be found to Jews, Muslims ('Saracens'), and their "dark visages, white turbans, and the Oriental form of their garments" (37).

Moreover, Scott's medieval story is a response to the "problem of two forms of identity in conflict: European national identity and Jewish identity" (Ragussis 181). The time Scott was writing Ivanhoe coincided with the so-called Hep! Hep! Riots (1819) - the anti-Semitic furore against Ashkenazi Jews that started in Bavaria, Germany, and then spread as the 'Jewish Question'

\footnotetext{
${ }^{1}$ In the $2^{\text {nd }}$ half of the $18^{\text {th }}$ century Edinburgh emerged as the 'Athens of the North' and the center of the Scottish Enlightenment; Scott was hugely influenced by this intellectual movement. Scottish Enlightenment historiography saw history in an evolutionary progress.
} 
throughout Europe. "In the guise of a medieval romance, then, Scott was addressing the ways in which contemporary European nations were working out the conflict between the rise of nationalism and the claims made on behalf of Jewish emancipation" (ibid. 182). The main subject of the novel is therefore the age-old opposition of the self (the native) and the other (the foreign).

In Ivanhoe the way the Jews are treated by Saxons and Normans is very revealing. Though the way Rebecca is treated by English Ivanhoe is contrasted to rude behavior of the "atheistic" Norman Bois-Guilbert, in a larger picture both Saxons and Normans are cruel to the Jews, only in different degrees. Cedric the Saxon calls them "the whole nation of stiff-necked unbelievers" and "constrain[s] no man to converse or to feed with [them] (Scott, 1996: 63); they are equally called "unbelieving" Jews by Normans. Since religion (Christianity) has always been a determining factor in the making of English national identity, being a Jew might stir problems unless they are converted. In 1809 the London Society for Promoting Christianity amongst the Jews was founded. The idea was to wipe out the anxiety of difference, to turn 'them' into 'us.' We should notice that the time Ivanhoe narrates is "the historical epoch in which the national identity of England took shape" (Ragussis 187) and this new nationalism of medieval England looked for a religious homogeneity. That is why at the end of the novel Rebecca leaves Christian England for Spain; "her voluntary exile anticipates the forced expulsion of the Jews from England in 1290, the earliest general expulsion of the Jews in medieval history" (203). Rowena's reaction to Rebecca's selfimposed exile is also interesting; she tries to convince her to abandon her Jewish faith, to which Rebecca sarcastically replies: "No, lady ... that may not be. I may not change the faith of my fathers like a garment unsuited to the climate in which I seek to dwell" (Scott, 1996: 501).

Equally important is the ending of the novel, mainly for two reasons. Upon his return, "Richard Plantagenet" refuses to be called "Richard of Anjou" and calls himself "Richard of England! whose deepest interest, whose deepest wish, is to see her sons united with each other"; he then promises "equal protection of Normans and English" (470). Accordingly, Scott accounts for his theory racial and cultural hybridity. The marriage of Rowena and (the Normanized) Ivanhoe attests to this productive union of Saxons and Normans.

After all, Scott's attitude towards national politics, which is simply and unyieldingly to maintain the status quo, finds stronger and more critical resonance in the works of the chief midVictorian novelist, Charles John Huffam Dickens (1812-1870). More than any other mid-Victorian writer, Dickens embodies the Englishness of the English novel; he was a national icon. George Gissing (1857-1903) once said, "[Dickens'] art, splendidly triumphant, made visible to all mankind the characteristic virtues, and the typical shortcomings, of the homely English race" (cited in Parrinder 213).

\section{Nation and Vernacular: Charles Dickens}

National literature as an idea is not conceivable without national language. With the dawn of the Renaissance and its emphasis upon the use of vernacular as national language, prose and prosewriting gained more stature progressively-until it reached the age of novel in English literature: the mid-Victorian period.

Mid nineteenth-century historical novels sought a necessary conflation of nation and vernacular; "The new middle-class intelligentsia of nationalism had to invite the masses into history, and the invitation-card had to be written in a language they understood" (Tom Nairn, cited in Anderson 8o). It is for instance easier to read Dickens' national narrative A Tale of Two 
Cities than Scott's Waverley; his journalistic style walks the reader easily through the events and their meanings, and no demanding code-switching to Gaelic is involved.

Speaking of A Tale of Two Cities (1859), Dickens was a relentless critic of the society of his time and its vices; he was a moral reformer: "Dickens's nationalism takes the form of a moral rather than a political concern about the condition of England. He parodies boastful nationalism as a brand of complacency that works against the country's best moral interests" (Saville 784). In $A$ Tale Dickens voices his concern about-and fear indeed of - the Chartist ferments and the threat of revolution. He is so alarmed to say "in England, there was scarcely an amount of order and protection to justify much national boasting" (Dickens, 2005: 43). The target of his criticism is "a parochial English populace that blinds itself to its own moral shortcomings" (McBratney 535). He surely does not desire "this raging Revolution that was running so fearfully wild" in France for England (Dickens, 2005: 324). Therefore, he takes the reader "backwards and forwards between France and England" to contrast the former's turmoil with the latter's peace (83); hence, the opening:

It was the best of times [English stability], it was the worst of times [French turmoil], it was the age of wisdom, it was the age of foolishness, it was the epoch of belief, it was the epoch of incredulity, it was the season of Light, it was the season of Darkness, it was the spring of hope, it was the winter of despair. (7)

Through this contrast, Dickens reinforces English nationalism and at the same time berates the French version of nationalism which is chaotic and violent. It is interesting that the violence in Dickens' novels is "explicitly non-English" (de Groot 35). It was in reaction to the Other beyond their borderlines that the English came to define their character and identity-a classic strategy in nationalist politics. The idea of 'self versus other' is also visible in another of Dickens' major novels Great Expectations (1861); it describes a common pattern of relationships between the metropole and its imperial outposts, between center and colonial periphery. Abel Magwitch is caught at "the rough midpoint along the axis joining imperial metropole and colony" (McBratney 529); his national identity is indeterminate. He is a symbol of the anxiety of belonging. Indeed, the word 'home' loses its accustomed meaning for Magwitch and other outsiders like him.

That Pip dislikes Magwitch is not so much related to his being a convict than to an "English antipathy to colonial Australia" (Dickens, 2005: 538). English colonial discourse and its imaginative geography "demonized Autralia" as the "continent of $\sin "$ (538). That is why there is no home in England for a returned convict as Magwitch, who might have 'gone native.' According to Edward Said (1935-2003),

Australia was established as a penal colony in the late eighteenth century mainly so that England could transport an irredeemable, unwanted excess population of felons to a place, originally charted by Captain Cook, that would also function as a colony replacing those lost in America. The pursuit of profit, the building of empire, and what Hughes calls social apartheid together produced modern Australia. ... Dickens first took an interest in it during the 1840s. (xvi)

Besides Australia, Egypt is also mentioned as an imperial outpost of progress. There is no question today that imperialism was partly powered by capitalist expansion. The need to find new sources for financial capital and new profitable markets was the reason behind Britain's imperial adventures in the Orient. At the end of the novel Pip leaves London for Cairo for "two little words, more capital" (Dickens, 2008: 141): "What alone was wanting to the realization of a vast fortune, he considered to be More Capital" (141). "In his new career as colonial businessman, Pip is hardly 
an exceptional figure, since nearly all of Dickens' businessmen, wayward relatives, and frightening outsiders have a fairly normal and secure connection with the empire" (Said xvii). Dickens' own sons were in the East, serving the British Empire: "Charley's in Hong Kong, Sydney's at sea, Walter's in India, and Alfred and Edward in Australia" (McBratney 540). This was seemingly a popular fantasy amongst nineteenth-century British writers and readers: to go and strike it rich in the Orient. The most famous literary example is perhaps Rudyard Kipling's The Man Who Would Be King (1888). Kipling's story describes two con men named Peachey Carnehan and Daniel Dravot who follow the ideal of Empire in Kafirstan (in Afghanistan): "we'd be an Empire. When everything was shipshape I'd hand over the crown-this crown I'm wearing now-to Queen Victoria on my knees, and she'd say, "Rise up, Sir Daniel Dravot" (26). They are in the East to work out their childhood fantasies, just like Pip in Great Expectations who "sketch[s] airy pictures of himself conducting Clara Barley to the land of the Arabian Nights ... (with a caravan of camels, I believe)" (381). Both descriptions are fueled by naive orientalist stereotypes. Here, as in Great Expectations, "the economic desire propelled middle class men like him [Pip], who lacked business openings at home, to venture to the margins of the Empire to seek wealth and power" (McBratney 537). "In many other Dickens' novels business men have connections with the empire, Dombey and Quilp being two noteworthy examples" (Said 74). We should not undervalue the role of Protestantism and its idea of self-help and self-interest. In 1905 Adam Smith published his famous tract The Protestant Ethic and the Spirit of Capitalism which regards the Protestant work ethic the main idea behind the emergence of capitalism. The pursuit of profit and self-benefit is a virtuous calling in Protestantism. English nation's greatness in the nineteenth century lied within the bounds of these colonial margins.

In 1868, radical imperialist Sir Charles Wentworth Dilke (1843-1911) wrote Greater Britain to justify his thesis that Britons are a superior race and thus support imperial expansionism-a project that started in the sixteenth century and reached its full-blown stage in the late nineteenth century.

Nonetheless George Eliot (1819-1880) "warns against [this] mass immigration, which would put the 'distinctive national characteristics' of a historic people such as the English 'in danger of obliteration by the predominating quality of foreign settlers"' (Parrinder 237). She was afraid the master English race loses some of its unique quality along the way. Although many have highlighted Eliot's moral consciousness and moral realism, and she seems to be-based at least on the above quotation-critical of English expansionist ideology, she "could produce no concept of Englishness that did not accept the colonies and colonialism as integral to the national character" (Henry 430). She was both a product and partly a producer of the dominant imperial discourse of the time and, like other major writers of the period, was following and-willingly or unwillinglycontributing to the racial ideology of 'self versus other.' The prevailing view on this subject was put forth by Benjamin Disraeli (1804-1881) - author of Tancred or the New Crusade (1847), part of the 'Young England' trilogy—that "all is race; there is no other truth" (cited in Brantlinger 268). In The Races of Man (1862) Robert Knox summarized the whole attitude of the Victorian society towards race: "Race is everything: literature, science, art, in a word, civilization depends on it" (cited in Purchase 112). Victorian fear and obsession with 'race' was "a product of centuries of British involvement in slavery and imperialism ... This conception was, in turn, both partly constructed and reaffirmed by the rise of the biological sciences, by discourses of anthropology and Orientalism, and especially by the sinister theories which grew out of 'scientific racism' [e.g. phrenology, eugenics etc.]" (Purchase 112). 
In Middlemarch: A Study of Provincial Life (1871) George Eliot measures provincial life in England against "ruins, confusion, [and] destruction" of Rome (Hardy 13). While Casaubon is stuck in "ruin and confusing changes" in Rome (Eliot 12), Dorothea desires "to lead a grand life here-now-in England" (19), she just cannot relate to

[R] uins and basilicas, palaces and colossi, set in the midst of a sordid present, where all that was living and warm-blooded seemed sunk in the deep degeneracy of a superstition divorced from reverence; the dimmer but yet eager Titanic life gazing and struggling on walls and ceilings; the long vistas of white forms whose marble eyes seemed to hold the monotonous light of an alien world: all this vast wreck of ambitious ideals, sensuous and spiritual, mixed confusedly with the signs of breathing forgetfulness and degradation, at first jarred her as with an electric shock, and then urged themselves on her with that ache belonging to a glut of confused ideas which check the flow of emotion. (124)

Dorothea cannot wait to go back to England; "George Eliot does not erase the image of English home but puts it in its place, geographically and physically. It is not rejected, but valued and revalued" (Hardy 15). After all, Eliot was writing at the time of the so-called 'Scramble for Africa' where the British Empire was rivaling other European powers, and it seemed only natural for the writers of the era to reflect, consciously or unconsciously, anxieties about self/other, race, and identity.

Many of the late nineteenth-century historical novels are therefore related to the Empire one way or another. Even writers of children's novels and juvenile adventure stories filled their tales with ideological salutes to the Empire. One of these writers was the famous George Alfred Henty (1832-1902); "The general sweep of his books is the nationalistic perfection of the British, and this is particularly achieved through military conquest and victory" (de Groot 89). The rise to power of Germany in Europe's power politics, especially in the 1870s, and the menacing presence of Russia, especially around the second and the third Afghan Wars (1878-1880), made the idea of Greater Britain look more and more justifiable (to the English of course). In all, "Imperialism awakened a new sense of Englishness ... a new sense of English racial identity" (Gilmour 184).

The more we approach the twentieth century, however, the less popular we find the historical novel. Besides, the few distinguished late-Victorian examples suggest the structural drift of these fictional attempts towards probing the impact of external historical events upon the internal individual psyche-a praxis reaching its apex during the modernist era. We may accordingly consider George Eliot and Thomas Hardy (1840-1928) transitional figures who were led to regard previous work in the genre as insufficient. For these writers, history and the historical events are valuable "merely because they have happened to people, have mixed themselves with personal fortunes, have been permeated by human emotions, and have been remembered" (Fleishman 184). Here the idea of remembering and belonging comes to the fore. Overall, what we can see clearly towards the end of the $19^{\text {th }}$ century is that the classical pattern of historical novel gradually loses its viability.

\section{Epilogue}

Historical novels of pre-modern era generally fall into two main categories of romances and novels of character. In the former type, the emphasis is upon the events or adventures that the hero undertakes on their historical quest, while in the latter the emphasis is on characterization and then on plot; in other words, we are no longer dealing with 'type's but 'character's. Sir Walter Scott's Ivanhoe falls within the first category and his Waverley within the second. 
When we move on to the modern era and consider the modernist style of narration, we witness a meaningful shift in approaching history. Modernist historical novels are not about history per se but about 'consciousness of history.' Modernist writers of historical novels did not put their pens to paper with this idea in mind of creating a detailed historiographic piece. They treated history as it was received in the minds of their characters. Virginia Woolfs Between the Acts is such a novel: here we are no longer encountered with causal relationships of events taken with extreme precision from the archives of history; instead, we are presented with a kind of 'mind time' and 'mind history.' All in all, Historical novels, like many other literary or artistic forms, can strengthen or undermine national identity.

\section{References:}

Anderson, Benedict. (1991). Imagined Communities: Reflections on the Origin and Spread of Nationalism. London: Verso.

Benjamin, Walter. (2007). Illuminations. Edited with an Introduction by Hannah Arendt. New York: Schocken Books.

Bhabha, Homi K. ed. (1990). Nation and Narration. London and New York: Routledge.

Brantlinger, Patrick. "Nations and Novels: Disraeli, George Eliot, and Orientalism," Victorian Studies 35, 3 (1992): 255-275.

Defoe, Daniel. (2007 [1719]). Robinson Crusoe. Ed. Thomas Keymer. Oxford: Oxford University Press.

De Groot, Jerome. (2010). The Historical Novel. London and New York: Routledge.

Dickens, Charles. (2005 [1859]). A Tale of Two Cities. San Diego: Thesaurus Edition, ICON Group International.

Dickens, Charles. (2008 [1861]). Great Expectations. Oxford: Oxford World Classics.

Eliot, George. (200o [1872]). Middlemarch. Edited by Bert G. Hornback. New York: W. W. Norton \& Company.

Engel, Steven T. (2005). "Rousseau and Imagined Communities," The Review of Politics 67, 3: 515-537.

Fleishman, Avrom. (1971). The English Historical Novel: Walter Scott to Virginia Woolf. Baltimore and London: The Johns Hopkins Press.

Gellner, Ernest. (2006). Nations and Nationalism. Oxford: Blackwell.

Gilmour, Robin. (1993). The Victorian Period: The Intellectual and Cultural Context of English Literature, 1830-1890. London and New York: Longman.

Hardy, Barbara. (1993). "Rome in Middlemarch: A Need for Foreignness," George Eliot - George Henry Lewes Studies 24/25: 1-16.

Hayden, John O. ed. (2003 [1970]). Walter Scott: The Critical Heritage. London and New York: Routledge.

Henry, Nancy. (2001). "George Eliot and the Colonies," Victorian Literature and Culture 29, 2: 413-433.

Higson, Andrew. (2010). Film England: Culturally English Filmmaking since the 1990s. London: I. B. Tauris.

Humphrey, Richard. (1993). Landmarks of World Literature: Scott's Waverley. Cambridge: Cambridge University Press.

Kipling, Rudyard. (2003). The Man Who Would Be King. A Penn State Electronic Classics Series Publication. 
Lowe, Norman. (1998). Mastering Modern British History. $3^{\text {rd }}$ ed. New York: Palgrave.

Lukács, Georg. (1989 [1937]). The Historical Novel. Trans. Hannah and Stanley Mitchell. London: Merlin Press.

McBratney, John. (2010). "Reluctant Cosmopolitanism in Dickens' Great Expectations," Victorian Literature and Culture 38, 2: 529-546.

Parrinder, Patrick. (2006). Nation and Novel: The English Novel from its Origins to the Present Day. Oxford: Oxford University Press.

Purchase, Sean. (2006). Key Concepts in Victorian Literature. New York: Palgrave.

Ragussis, Michael. (1993). "Writing Nationalist History: England, the Conversion of Jews, and Ivanhoe," ELH 6o, 1: 181-215.

Renan, Ernest. (1990 [1882]). "What Is a Nation?" Nation and Narration. Ed. Homi K. Bhabha. London and New York: Routledge.

Said, Edward. (1994). Culture and Imperialism. London: Vintage.

Saville, Julia F. (2002). "Eccentricity as Englishness in David Copperfield," Studies in English Literature, 150o1900 42, 4: 781-797.

Scott, Walter. Ivanhoe. (1996 [1820]). With an Introduction and Notes by Ian Duncan. Oxford: Oxford University Press.

Scott, Walter. (2013 [1814]). Waverley or 'Tis Sixty Years Since. A Penn State Electronic Classics Series Publication.

Masoud Farahmandfar is a PhD candidate in English literature at Shahid Beheshti University (Iran). His doctoral dissertation concentrates on a reading of contemporary English historiographic metafictional novels informed by theories of nationhood. He has written and translated a number of books and articles in Persian and English. His main research interests include postcolonial literature, nation(-alism) and the historical novel.

Dr Sarah Catherine Household-Ilkhani is a professor of English literature at Shahid Beheshti University (Iran). After gaining a BA (Hons) in French and History from the University of Surrey (England), she went on to obtain a Master's degree in English Literature from the Université Catholique de Louvain (Belgium) and a DEA in Comparative Literature (specializing in the eighteenth and nineteenth century French and English novel) from the Sorbonne (Paris, France). She continued her studies at the Université Libre de Bruxelles (Belgium) where she wrote her doctoral thesis on Sir Walter Scott. Her research interests include national identity, postcolonialism, the historical novel and the relationship between history and literature. She has published on Scott, national identity and contemporary novels. 